\title{
Growth and yield of shallots (Allium cepa var aggregatum L.) under different seed bulbs storage period
}

\author{
Rismawita Sinaga ${ }^{1 *}$, Nurmalita Waluyo $^{2 * *}$, Astiti Rahayu ${ }^{2}$, and Rini Rosliani ${ }^{2}$ \\ ${ }^{1}$ Lampung Assessment Institute for Agricultural Technology, ZA Pagar Alam, 1A, Rajabasa, \\ Lampung \\ ${ }^{2}$ Indonesian Vegetables Research Institute, Tangkuban perahu street, 517, Lembang, West Java
}

\begin{abstract}
The availability of qualified and sustainable seeds is one of the determinants of the success of shallot farming. One of the constraints factor in the supply of shallot seeds is the short storage period that is about 2-3 months. This study aims to determine the effect of varieties and seed storage period on growth and yield shallots. This research was conducted at Indonesian Vegetables Research Institute, Lembang, West Java, Indonesia. The study was designed using split plot design with four replications. The main plot was seed storage period for four months, five months and six months after harvest and the subplot was varieties, consisting of seven varieties that have been released, namely Bima Brebes, Katumi, Kuning, Pikatan, Trisula, Pancasona and Mentes. The results showed that the yield of wet bulbs per hectare of five-months- storage period bulb seeds was significantly higher than six months storage period for the varieties of Bima Brebes, Katumi, Kuning, Pikatan, Pancasona and Mentes. Five-months-storage period of shallot bulb seeds can still be used as a source of seeds for the varieties of Bima Brebes, Katumi, Kuning, Pikatan, Pancasona and Mentes.
\end{abstract}

\section{Introduction}

Shallots (Allium cepa L. var. aggregatum) is one of the important commodities in the development of vegetables in Indonesia which is used as a complement to daily cooking spices and also as traditional medicine. Shallot production in Indonesia in 2018 reached $1,503,436$ tons and increased in 2019 by $1,580,247$ tons or $5.11 \%$ with productivity reaching 9.59 tons per hectare in 2018 with an increase in 2019 of 3.55\% (9.93 tons per hectare). The area of shallot land every year also increases from 156.779 hectares in 2018 , to 159.195 hectares in 2019 or an increase of 1.54\%) [1]. With the increase in the area of planting shallots every year, the need for seeds will also increase.

One of the keys to the success of a crop cultivation system, including vegetables, is the use of quality seeds, which include physiological, genetic, and physical qualities. The

\footnotetext{
* Corresponding author: rismawitasinaga@yahoo.com

** Corresponding author: nurmalitawaluyo@gmail.com
} 
production and quality of vegetable products is highly dependent on the quality of the seeds used. This is because the genetic potential of superior vegetable varieties will appear optimally if quality seeds are used. Data from the Directorate of Horticultural Seeds [2] showed that the availability of quality vegetable seeds has not been able to provide the sufficient needs. Currently, the supply of shallots is constrained by the storage period in the seed storage, which is about 2-3 months. So that when the production of shallots for seeds or for consumption of available seeds is more than 2-3 months storage periode, so the results obtained are not as expected because the seeds are old.

Shallot seeds that are good for planting are those that do not contain disease, are not deformed and are not stored for too long (4 months) in a warehouse. Climate change is happening so that the production of shallots including seeds is erratic and the lack of shallot seed breeders causes the supply of shallot seed bulbs not necessarily available when needed. So farmers use the seeds that are available at the period of planting. According to Giamerti and Mulyaqin [3] the shelf life of shallot seedlings for 10 weeks is better than the shelf life of 7 weeks.

This study aims to determine the effect of varieties and seed storage period on growth, yield components and yield of shallots.

\section{Materials and methods}

The research was conducted at the Margahayu Experimental Farm, Indonesian Vegetables Research Institute, Lembang, at an altitude of 1,250 m asl. The source of shallot seeds was obtained from Source Seed Management Unit of Indonesian Vegetables Research Institute (UPBS Balitsa) from same seed lot (same location and production period). The study was arranged in a Split Plot Design with four replications, one replication consisting of 100 plants. The main plot was the seed storage period, which were 4 months, 5 months and 6 months after harvesting and the subplots were varieties, consisting of 7 varieties i.e. Bima Brebes, Katumi, Kuning, Pikatan, Trisula, Pancasona and Mentes. The plots were arranged with a size of $1 \times 3 \mathrm{~m}$ (width $\mathrm{x}$ length), consisting of 100 plant with planting space of $20 \mathrm{x}$ $15 \mathrm{~cm}$.

Before planting, shallot bulb seeds were stored in a room with a temperature of $29-30^{\circ} \mathrm{C}$ and humidity $60-70 \%$. Bulbs seed are put in waring. Planting using black plastic mulch. The basic fertilizers given before planting were organic fertilizer ( 15 ton/ha), dolomite $(1.5$ ton/ha) and SP-36 (250 kg/ha). Subsequent fertilization is given at 2, 4 and 6 weeks after planting (WAP) by watering using NPK 16-16-16 (8 g/l water) as much as $100 \mathrm{ml} / \mathrm{plant}$. Maintenance includes weeding, watering and controlling pests and diseases. Pest and disease control is carried out by spraying pesticides according to the pest attack. Irrigation and weeding are carried out according to the growth stage.

The observed parameters are growth characters, yield components and yields. Data were taken from ten sample plants per treatment. Growth characters observed, i.e. plant height, number of tillers per cluster, number of leaves per cluster were observed at the age of 30 , 45 , and 60 days after planting (HST); and the weight of chlorophyll $(\mathrm{mg} / \mathrm{g})$, leaf area $(\mathrm{cm} 2)$ and the plant dry weight was observed at 30 days after planting. Harvesting was done when $80 \%$ of the plant population has fallen. Characteristics of yield and yield components observed, i.e. dry weight of plants at harvest $(\%)$, bulb diameter $(\mathrm{cm})$, number of bulbs per cluster, wet weight of bulb per cluster $(\mathrm{g})$, wet weight per bulb $(\mathrm{g})$, bulb dry weight per cluster (g), dry weight per bulb (g), weight loss (wet-dry bulb) (\%), wet weight of bulb per plot and per hectare, and dry weight of bulb per plot and per hectare. Analysis of variance using the STAR program was followed by a significant difference test using Tukey's HSD (BNJ) at 5\% significance. 


\section{Results and discussion}

\subsection{Plant growth}

There was no interaction between the storage period of seeds and varieties on the plant height and number of shallots at 30,45 and 60 DAP (Table 1). The highest plant height and number of leaves were shown at five months stored seeds. Kuning variety showed the highest plant height at the age of 30, 45 and 60 DAP. Pikatan variety showed the highest number of leaves at 30 and 45 DAP, while at 60 DAP the Katumi variety showed the highest number of leaves, although it was not significantly different from other varieties except the Trisula variety. This shows that the growth of shallots at seed storage period for 5-months was still good for the tested varieties, except for the Trisula variety. The process of forming shallot bulbs occurs after the cell division process takes place maximally with the formation of a number of leaves. The cells at the base of the shoot will then undergo a process of elongation and enlargement during carbohydrate filling [4]. Plant vegetative growth is influenced by the ability of plants to synthesize several protein components that are available and needed [5].

Table 1. Effect of storage period of seeds and varieties on the average plant height and number of leaves of shallot plants at 30, 45 and 60 DAP

\begin{tabular}{|c|c|c|c|c|c|c|}
\hline \multirow{2}{*}{ Treatment } & \multicolumn{3}{|c|}{ Plant height (cm) } & \multicolumn{3}{c|}{ Number of leaves } \\
\cline { 2 - 7 } & 30 DAP & 45 DAP & 60 DAP & 30 DAP & 45 DAP & 60 DAP \\
\hline \multicolumn{2}{|c|}{ Storage period of seeds (months) } & \multicolumn{5}{|c|}{} \\
\hline 4 & $20.13 \mathrm{~b}$ & $27.07 \mathrm{~b}$ & $30.35 \mathrm{~b}$ & $18.75 \mathrm{a}$ & $30.39 \mathrm{~b}$ & $39.29 \mathrm{a}$ \\
\hline 5 & $29.19 \mathrm{a}$ & $38.52 \mathrm{a}$ & $38.99 \mathrm{a}$ & $19.56 \mathrm{a}$ & $37.40 \mathrm{a}$ & $35.18 \mathrm{a}$ \\
\hline 6 & $18.09 \mathrm{~b}$ & $20.82 \mathrm{c}$ & $20.42 \mathrm{c}$ & $19.85 \mathrm{a}$ & $26.29 \mathrm{~b}$ & $28.18 \mathrm{a}$ \\
\hline Varieties & & & & & & \\
\hline Bima brebes & $22.76 \mathrm{a}$ & $30.38 \mathrm{a}$ & $31.74 \mathrm{ab}$ & $20.18 \mathrm{a}$ & $30.97 \mathrm{a}$ & $34.29 \mathrm{a}$ \\
\hline Katumi & $21.50 \mathrm{a}$ & $27.13 \mathrm{~b}$ & $27.92 \mathrm{c}$ & $21.03 \mathrm{a}$ & $33.95 \mathrm{a}$ & $38.11 \mathrm{a}$ \\
\hline Kuning & $23.33 \mathrm{a}$ & $30.34 \mathrm{a}$ & $32.13 \mathrm{a}$ & $18.44 \mathrm{ab}$ & $30.06 \mathrm{ab}$ & $35.07 \mathrm{a}$ \\
\hline Pikatan & $22.09 \mathrm{a}$ & $27.50 \mathrm{ab}$ & $28.08 \mathrm{bc}$ & $21.17 \mathrm{a}$ & $34.38 \mathrm{a}$ & $34.20 \mathrm{a}$ \\
\hline Trisula & $23.28 \mathrm{a}$ & $28.30 \mathrm{ab}$ & $29.41 \mathrm{abc}$ & $15.62 \mathrm{~b}$ & $24.35 \mathrm{~b}$ & $27.83 \mathrm{~b}$ \\
\hline Pancasona & $21.59 \mathrm{a}$ & $28.16 \mathrm{ab}$ & $29.31 \mathrm{abc}$ & $18.38 \mathrm{ab}$ & $30.75 \mathrm{a}$ & $32.18 \mathrm{ab}$ \\
\hline Mentes & $22.73 \mathrm{a}$ & $29.79 \mathrm{ab}$ & $30.85 \mathrm{abc}$ & $20.89 \mathrm{a}$ & $35.05 \mathrm{a}$ & $37.83 \mathrm{a}$ \\
\hline
\end{tabular}

Mean followed by the same letters are not significantly different according Tukey Test at P 0,05

The results of analysis of variance showed that there was no interaction between the storage period of seeds and varieties on the average number of tillers at 30 DAP (Table 2). The mean number of tillers at the age of 30 DAP in the 5 month storage period was significantly different than the 6 month storage period. This shows that the bulbs can still be used until 5 months storage period. The mean number of tillers at 30 DAP Bima Brebes variety (5.45), Katumi (6.03), Kuning (5.10), Pikatan (5.93), Pancasona (5.08) and Mentes (5.73) were significantly different than Trisula (4.28). The number of leaves has a positive correlation with tuber diameter, plant height and number of tillers although it has no correlation with tuber weight [6]. 
Table 2. Effect of storage period of seeds and varieties on the number of tillers of shallot plants at 30 DAP

\begin{tabular}{|c|c|}
\hline Treatment & Number of tillers \\
\hline $\begin{array}{c}\text { Storage period of } \\
\text { seeds (months) }\end{array}$ & \\
\hline 4 & $5.51 \mathrm{ab}$ \\
\hline 5 & $6.20 \mathrm{a}$ \\
\hline 6 & $4.41 \mathrm{~b}$ \\
\hline Varieties & \\
\hline Bima & $5.45 \mathrm{a}$ \\
\hline Katumi & $6.03 \mathrm{a}$ \\
\hline Kuning & $5.10 \mathrm{ab}$ \\
\hline Pikatan & $5.93 \mathrm{a}$ \\
\hline Trisula & $4.28 \mathrm{~b}$ \\
\hline Pancasona & $5.08 \mathrm{ab}$ \\
\hline Mentes & $5.73 \mathrm{a}$ \\
\hline
\end{tabular}

Mean followed by the same letters are not significantly different according Tukey Test at P 0,05)

The results of analysis of variance showed that there was an interaction between the storage period of seeds and varieties on the average number of tillers at 45 and 60 DAP (Table 3). The number of tillers increased with increasing of age of plant, and was not significantly different for bulb seeds storage period at 4,5 dan 6 months. The number of tillers at 45 and 60 DAP was significantly different between varieties at 5 and 6 months seed storage period. Trisula showed the least number of tillers than other varieties. This shows that plant growth is different for each variety, and is influenced by the storage period of seeds, the longer the age of the seeds, the number of tillers tends to decrease. A high number of tillers can produce a high number of bulbs, because each tiller that is formed will produce bulbs. The number of leaves and the number of tillers that have a lot of effect on the yield component. This is caused by increasing the results of photosynthesis produced by leaves. The number of bulbs produced by the shallot plant is closely related to the number of leaves. The number of leaves will affect the photosynthesis produced [7].

Table 3. Effect of interaction between seed storage period and varieties on number of tillers at 45 and 60 DAP

\begin{tabular}{|c|c|c|c|c|c|c|c|}
\hline Treatment & \multicolumn{7}{|c|}{ Varieties } \\
\hline $\begin{array}{c}\text { Seed storage period } \\
\text { (months) }\end{array}$ & Bima Brebes & Katumi & Kuning & Pikatan & Trisula & Pancasona & Mentes \\
\hline \multicolumn{8}{|c|}{ Number of tillers (45 DAP) } \\
\hline 4 & $\begin{array}{c}6.58 \mathrm{a} \\
\mathrm{A}\end{array}$ & $\begin{array}{c}7.63 \mathrm{a} \\
\mathrm{A}\end{array}$ & $\begin{array}{c}7.28 \mathrm{a} \\
\mathrm{A}\end{array}$ & $\begin{array}{c}7.03 \mathrm{a} \\
\mathrm{A}\end{array}$ & $\begin{array}{c}5.88 \mathrm{a} \\
\mathrm{A}\end{array}$ & $\begin{array}{c}6.13 \mathrm{a} \\
\mathrm{A}\end{array}$ & $\begin{array}{c}7.48 \mathrm{a} \\
\mathrm{A}\end{array}$ \\
\hline 5 & $\begin{array}{c}6.90 \mathrm{a} \\
\mathrm{AB}\end{array}$ & $\begin{array}{c}7.80 \mathrm{a} \\
\mathrm{A}\end{array}$ & $\begin{array}{c}5.88 \mathrm{a} \\
\mathrm{BC}\end{array}$ & $\begin{array}{c}8.15 \mathrm{a} \\
\mathrm{A}\end{array}$ & $\begin{array}{c}4.60 \mathrm{a} \\
\mathrm{C}\end{array}$ & $\begin{array}{c}7.73 \mathrm{a} \\
\mathrm{AB}\end{array}$ & $\begin{array}{c}7.33 \mathrm{a} \\
\mathrm{AB}\end{array}$ \\
\hline 6 & $\begin{array}{c}5.28 \mathrm{a} \\
\mathrm{BC}\end{array}$ & $\begin{array}{c}7.75 \mathrm{a} \\
\mathrm{A}\end{array}$ & $\begin{array}{l}6.03 \mathrm{a} \\
\mathrm{ABC}\end{array}$ & $\begin{array}{c}6.97 \mathrm{a} \\
\mathrm{AB}\end{array}$ & $\begin{array}{c}4.53 \mathrm{a} \\
\mathrm{C}\end{array}$ & $\begin{array}{l}6.25 \mathrm{a} \\
\mathrm{ABC}\end{array}$ & $\begin{array}{c}6.55 \mathrm{a} \\
\mathrm{AB}\end{array}$ \\
\hline \multicolumn{8}{|c|}{ Number of tillers (60 DAP) } \\
\hline 4 & $\begin{array}{c}7.23 \mathrm{a} \\
\mathrm{AB}\end{array}$ & $\begin{array}{c}8.85 \mathrm{a} \\
\mathrm{A}\end{array}$ & $\begin{array}{c}8.70 \mathrm{a} \\
\mathrm{AB}\end{array}$ & $\begin{array}{c}7.95 \mathrm{a} \\
\mathrm{AB}\end{array}$ & $\begin{array}{c}6.65 \mathrm{a} \\
\mathrm{B}\end{array}$ & $\begin{array}{l}7.08 \mathrm{a} \\
\mathrm{AB}\end{array}$ & $\begin{array}{c}8.60 \mathrm{a} \\
\mathrm{AB}\end{array}$ \\
\hline 5 & $\begin{array}{c}7.13 \mathrm{a} \\
\mathrm{AB}\end{array}$ & $\begin{array}{c}7.65 \mathrm{a} \\
\mathrm{AB}\end{array}$ & $\begin{array}{c}5.80 \mathrm{~b} \\
\mathrm{BC}\end{array}$ & $\begin{array}{c}8.33 \mathrm{a} \\
\mathrm{A}\end{array}$ & $\begin{array}{c}4.78 \mathrm{~b} \\
\mathrm{C}\end{array}$ & $\begin{array}{c}7.48 \mathrm{a} \\
\mathrm{AB}\end{array}$ & $\begin{array}{c}7.28 \mathrm{a} \\
\mathrm{AB}\end{array}$ \\
\hline 6 & $\begin{array}{c}5.56 \mathrm{a} \\
\mathrm{BC}\end{array}$ & $\begin{array}{c}7.98 \mathrm{a} \\
\mathrm{A}\end{array}$ & $\begin{array}{l}6.45 \mathrm{~b} \\
\mathrm{ABC}\end{array}$ & $\begin{array}{c}7.85 \mathrm{a} \\
\mathrm{A}\end{array}$ & $\begin{array}{c}4.65 \mathrm{~b} \\
\mathrm{C}\end{array}$ & $\begin{array}{l}6.53 \mathrm{a} \\
\mathrm{ABC}\end{array}$ & $\begin{array}{c}7.20 \mathrm{a} \\
\mathrm{AB}\end{array}$ \\
\hline
\end{tabular}

Numbers followed by the same capital letter in the same row and numbers followed by the same lowercase letters in the same column show no significant difference with Tukey's test at 0.05 
Table 4 shows that there was no interaction between seed storage period and varieties on the chlorophyll weight, leaf area, plant dry weight at 30 DAP and plant dry weight at harvest. The highest chlorophyll weight was at 4 months after storage although not different significantly with 5 and 6 months. Chlorophyll weight was not significantly different in all varieties, chlorophyll weight ranged between $1.35 \mathrm{mg} / \mathrm{g}$ (Bima brebes) and $1.62 \mathrm{mg} / \mathrm{g}$ (Katumi). The results of the study by Mashud [8] showed that the content of chlorophyll a, b and the total leaves of the three coconut varieties tested were not significantly different. Stomata and chlorophyll have a positive relationship with coconut yield. The positive effect of these two photosynthetic organs on coconut yields is determined by the number of leaves per tree [8]. Chlorophyll weight is the total content of chlorophyll a and chlorophyll $\mathrm{b}$ in the leaves. Chlorophyll is a pigment that plays a role in the photosynthesis process of plants by absorbing and converting light energy into chemical energy. The three main functions of chlorophyll in photosynthesis is the process of utilizing solar energy, triggering the fixation of $\mathrm{CO} 2$ to produce carbohydrates and provide energy for the ecosystem as a whole [9].

Leaf area has important influence in the photosynthesis process and is often used in plant growth analysis to study agronomic and physiological aspects [10,11]. Leaf area at storage period of 4 months $\left(175.81 \mathrm{~cm}^{2}\right)$ and 5 months $\left(216.93 \mathrm{~cm}^{2}\right)$ was significantly higher than 6 months $\left(75.87 \mathrm{~cm}^{2}\right)$. This indicates that the seed bulbs can be stored up to 5 months storage period. Leaf area was not significantly different in all tested varieties. Leaf area ranged between $131.96 \mathrm{~cm}^{2}$ (Pancasona) and $181.15 \mathrm{~cm}^{2}$ (Bima Brebes). The ability of leaves to produce photosynthate products is determined by productivity per unit leaf area and total leaf area. The energy produced is highly dependent on the ratio of external and internal leaves [12].

Table 4. Effect of seeds storage period and varieties on weight of chlorophyll $(\mathrm{mg} / \mathrm{g})$, leaf area $\left(\mathrm{cm}^{2}\right)$ and dry weight of plant (\%) at $30 \mathrm{DAP}$, and dry weight of plant at harvest ( \%)

\begin{tabular}{|c|c|c|c|c|}
\hline Treatment & $\begin{array}{c}\text { Weight of } \\
\text { chlorophyll } \\
(\mathrm{mg} / \mathrm{g})\end{array}$ & $\begin{array}{c}\text { Leaf area } \\
\left(\mathrm{cm}^{2}\right)\end{array}$ & $\begin{array}{l}\text { Dry weight of } \\
\text { plant } \\
\text { (\%) at } 30 \text { DAP }\end{array}$ & $\begin{array}{c}\text { Dry weight of } \\
\text { plant } \\
\text { at harvest } \\
(\%)\end{array}$ \\
\hline \multicolumn{5}{|c|}{ Seed storage period (months) } \\
\hline 4 & $1.57 \mathrm{a}$ & $175.81 \mathrm{a}$ & $13.97 \mathrm{a}$ & $16.01 \mathrm{a}$ \\
\hline 5 & $1.44 \mathrm{a}$ & $216.93 \mathrm{a}$ & $10.21 \mathrm{c}$ & $16.10 \mathrm{a}$ \\
\hline 6 & $1.48 \mathrm{a}$ & $75.87 \mathrm{~b}$ & $12.13 \mathrm{~b}$ & $11.57 \mathrm{~b}$ \\
\hline \multicolumn{5}{|l|}{ Varieties } \\
\hline Bima & $1.35 \mathrm{a}$ & $181.15 \mathrm{a}$ & $11.92 \mathrm{ab}$ & $15.54 \mathrm{a}$ \\
\hline Katumi & $1.62 \mathrm{a}$ & $164.39 \mathrm{a}$ & $11.86 \mathrm{ab}$ & $14.26 \mathrm{a}$ \\
\hline Kuning & $1.57 \mathrm{a}$ & $151.47 \mathrm{a}$ & $11.99 \mathrm{ab}$ & $14.64 \mathrm{a}$ \\
\hline Pikatan & $1.56 \mathrm{a}$ & $173.94 \mathrm{a}$ & $12.39 \mathrm{ab}$ & $13.69 \mathrm{a}$ \\
\hline Trisula & $1.41 \mathrm{a}$ & $132.06 \mathrm{a}$ & $12.77 \mathrm{a}$ & $14.68 \mathrm{a}$ \\
\hline Pancasona & $1.43 \mathrm{a}$ & $131.96 \mathrm{a}$ & $12.10 \mathrm{ab}$ & $14.59 \mathrm{a}$ \\
\hline Mentes & $1.54 \mathrm{a}$ & $158.48 \mathrm{a}$ & $11.69 \mathrm{~b}$ & $14.51 \mathrm{a}$ \\
\hline
\end{tabular}

Mean followed by the same letters are not significantly different according Tukey Test at P 0,05

The percentage of plant dry weight is the percentage of dry weight content contained in the plant. Table 4 shows the percentage of dry weight of plants at harvest was higher than dry weight at 30 DAP. This shows that during growth there is an accumulation of photosynthetic results which increases the dry weight of the plant. There was no interaction between the storage period of seeds and varieties on plant dry weight. The dry weight of the plant at 30 DAP showed the highest dry weight at the storage period of 4 months $(10.21 \%)$ which was significantly different from the seed storage period of 5 months $(10.21 \%)$, and 6 
months $(12.13 \%)$. Trisula variety had significantly higher plant dry weight than Mentes variety. The dry weight of the plant at harvest showed that the dry weight at the age of 4 months and 5 months was significantly higher than the 6 month storage period. Plant dry weight at harvest was not significantly different in all varieties, where dry weight ranged from 13.69-15.54\%. Leaves are the main organs responsible for photosynthetic activity. Therefore, the amount of leaf dry matter increased as a result of the increase in the number of leaves and the total leaf area [13]. The results of research on garlic showed that garlic bulbs began to develop after 60 days of plant growth, along with the increased photosynthetic efficiency of leaves [14].

The growth and development of bulbs depends on adequate translocation of photosynthetic substrates from the leaves to the bulb. Warm temperatures have been identified to promote the translocation of photosynthetic substrates from leaves to bulbs [15]. Translocation of photosynthetic substrate to bulbs begins after the shoot growth stage. And during the bulb growth stage, there is an increase in the dry weight of the bulb [13].

\subsection{Yield components}

There is no interaction between the storage period of seeds and varieties on all of these yield components. Seeds stored for 5 months showed the highest yield component compared to other storage period, except for the character of the number of bulbs per cluster, the storage period of 4 months was significantly higher than the other storage period. The yield component of 5 months after storage is better than other storage period, in line with the character of plant growth at storage period of 5 months which is better than other storage period. This shows that this yield component is influenced by plant growth. The environment for planting shallot bulbs with different seed storage period causes different cropping environmental conditions. Growth, yield components and yields are influenced by genetics, environment, and the interaction between the genotype and the environment. The results of research by [16] showed that garlic planted early produced bulbs that were larger than those planted late, because the plants did not receive a long period of cold growth, which is important for proper bulb development, this is due to environmental influences. different between early and late planted plants.

The diameter of the bulbs of the varieties tested was not significantly different. The diameter of the bulbs ranges from 1.81-1.85 cm, the diameter of this bulb is classified as quality I. According to Azmi [17], consumption of shallot bulbs with a minimum diameter of $1.7 \mathrm{~cm}$ are included in quality I and bulb of shallots with a minimum diameter of $1.3 \mathrm{~cm}$ are included in quality II. The number of bulbs per cluster ranged between 6.13 (Trisula variety) and 8.59 (Mentes variety). The low number of bulbs per cluster of the Trisula variety was comparable to the low number of tillers at 30, 45, and 60 DAP. According to research by [17] the character of the number of shallot bulbs is largely influenced by genetic factors and slightly influenced by the environment for the variety of Bima, Maja and Sumenep.

Wet weight of bulb/cluster of tested varieties ranged from 40.09-53.49 g. The wet weight of bulb/cluster of Mentes variety was significantly higher than that of Trisula variety. The low wet weight of bulbs per cluster of Trisula variety was comparable to the low number of leaves at 30,45, and 60 DAP, otherwise for Mentes variety. The growth and development of bulbs depend on adequate translocation of photosynthetic substrates from leaves to bulbs [13]. 
Table 5. Effect of seeds storage period and varieties on bulb diameter $(\mathrm{cm})$, number of bulbs per cluster, wet weight of bulbs per cluster (g), wet weight per bulb (g), dry weight of bulb per cluster ( $\mathrm{g}$ ), and dry weight per bulb $(\mathrm{g})$

\begin{tabular}{|c|c|c|c|c|c|c|}
\hline Treatment & $\begin{array}{c}\text { Bulb } \\
\text { Diameter } \\
(\mathbf{c m})\end{array}$ & $\begin{array}{c}\text { Number of } \\
\text { bulbs per } \\
\text { cluster }\end{array}$ & $\begin{array}{c}\text { Wet weight of } \\
\text { bulbs per } \\
\text { cluster (g) }\end{array}$ & $\begin{array}{c}\text { Wet weight } \\
\text { per bulb } \\
(\mathbf{g})\end{array}$ & $\begin{array}{c}\text { Dry weight } \\
\text { of bulb per } \\
\text { cluster (g) }\end{array}$ & $\begin{array}{c}\text { Dry weight } \\
\text { per bulb } \\
(\mathbf{g})\end{array}$ \\
\hline \multicolumn{7}{|c|}{ Seed storage period (months) } \\
\hline 4 & $1.95 \mathrm{a}$ & $8.48 \mathrm{a}$ & $50.91 \mathrm{~b}$ & $6.03 \mathrm{~b}$ & $35.71 \mathrm{a}$ & $4.22 \mathrm{~b}$ \\
\hline 5 & $2.12 \mathrm{a}$ & $7.24 \mathrm{~b}$ & $66.26 \mathrm{a}$ & $9.43 \mathrm{a}$ & $42.65 \mathrm{a}$ & $6.04 \mathrm{a}$ \\
\hline 6 & $1.43 \mathrm{~b}$ & $7.30 \mathrm{~b}$ & $26.64 \mathrm{c}$ & $3.71 \mathrm{c}$ & $14.00 \mathrm{~b}$ & $1.94 \mathrm{c}$ \\
\hline \multicolumn{7}{|c|}{ Varieties } \\
\hline Bima & $1.84 \mathrm{a}$ & $7.25 \mathrm{bc}$ & $52.85 \mathrm{ab}$ & $7.38 \mathrm{a}$ & $33.31 \mathrm{a}$ & $4.61 \mathrm{a}$ \\
\hline Katumi & $1.81 \mathrm{a}$ & $8.51 \mathrm{ab}$ & $48.88 \mathrm{ab}$ & $5.75 \mathrm{ab}$ & $32.48 \mathrm{a}$ & $3.80 \mathrm{a}$ \\
\hline Kuning & $1.84 \mathrm{a}$ & $7.39 \mathrm{abc}$ & $49.57 \mathrm{ab}$ & $6.97 \mathrm{ab}$ & $30.23 \mathrm{ab}$ & $4.24 \mathrm{a}$ \\
\hline Pikatan & $1.81 \mathrm{a}$ & $8.51 \mathrm{ab}$ & $45.32 \mathrm{ab}$ & $5.26 \mathrm{~b}$ & $31.79 \mathrm{ab}$ & $3.68 \mathrm{a}$ \\
\hline Trisula & $1.85 \mathrm{a}$ & $6.13 \mathrm{c}$ & $40.09 \mathrm{~b}$ & $6.93 \mathrm{ab}$ & $24.30 \mathrm{~b}$ & $4.22 \mathrm{a}$ \\
\hline Pancasona & $1.84 \mathrm{a}$ & $7.34 \mathrm{abc}$ & $45.36 \mathrm{ab}$ & $6.11 \mathrm{ab}$ & $29.43 \mathrm{ab}$ & $3.93 \mathrm{a}$ \\
\hline Mentes & $1.85 \mathrm{a}$ & $8.59 \mathrm{a}$ & $53.49 \mathrm{a}$ & $6.34 \mathrm{ab}$ & $33.96 \mathrm{a}$ & $4.00 \mathrm{a}$ \\
\hline
\end{tabular}

Mean followed by the same letters are not significantly different according Tukey Test at P 0,05

The wet weight per bulb of the varieties tested ranged from 5.26-7.38 g. Mentes variety was significantly higher than Trisula variety. The wet weight per bulb depended on the number of bulbs per cluster. Generally, plants that have large bulbs will have a small number of bulbs per cluster. In addition to the environment, the large size of shallot bulbs is influenced by genetic factors [7]. Cultivation of various varieties on the same plot showed different bulb sizes depending on the variety. El Zohiri and Faraq [16] reported garlic of White Super variety produced the highest clove and bulb weight and both characters reflected the highest total yield per feddan followed by Sids- 40 variety. Balady variety gave lower yields during this two seasons study. There were significant differences between the Sids-40 and Balady varieties due to genetic variation among varieties and their ability exploit environmental sources mainly light, $\mathrm{CO}_{2}$, water and nutrients.

The dry weight of bulbs per cluster and dry weight per bulb of the varieties tested ranged from 24.30-33.96 g and 3.68-4.61 g, respectively (Table 5). The dry weight of bulbs per cluster depended on weight loss (wet-dry bulbs). The higher the weight loss, the lower the dry weight of bulbs per cluster and dry weight per bulb.

Table 6 shows that there is an interaction between the storage period and varieties on weight loss. The lowest wet-dry weight loss was found in 4 month storage period of Bima brebes variety $(23.41 \%)$ and the highest was found in 6 month seed storage period of Bima brebes variety $(54.31 \%)$. The results of the research by Firmansyah and Bhermana [7] showed that the weight loss of four shallot varieties ranged from 27.3 to $34.9 \%$. This weight loss depends on the variety, different varieties will have different weight loss. 
Table 6. The interaction effect of seed storage period and varieties on weight loss (wet-dry bulbs) (\%)

\begin{tabular}{|c|c|c|c|c|c|c|c|}
\hline \multirow{2}{*}{ Treatment } & \multicolumn{7}{|c|}{ Varieties } \\
\hline & Bima & Katumi & Kuning & Pikatan & Trisula & Pancasona & Mentes \\
\hline & \multicolumn{7}{|c|}{ Seed storage period (months) } \\
\hline & \multicolumn{7}{|c|}{ weight loss (wet-dry bulbs) (\%) } \\
\hline 4 & $\begin{array}{c}23.41 \mathrm{c} \\
\mathrm{B}\end{array}$ & $\begin{array}{c}28.21 \mathrm{~b} \\
\mathrm{AB}\end{array}$ & $\begin{array}{c}31.62 \mathrm{c} \\
\mathrm{AB}\end{array}$ & $\begin{array}{c}24.53 \mathrm{~b} \\
\mathrm{~B}\end{array}$ & $\begin{array}{c}37.70 \mathrm{~b} \\
\mathrm{~A}\end{array}$ & $\begin{array}{c}29.02 \mathrm{~b} \\
\mathrm{AB}\end{array}$ & $\begin{array}{c}30.72 \mathrm{~b} \\
\mathrm{AB}\end{array}$ \\
\hline 5 & $\begin{array}{c}36.74 \mathrm{~b} \\
\mathrm{~A}\end{array}$ & $\begin{array}{c}33.99 \mathrm{~b} \\
\mathrm{~A}\end{array}$ & $\begin{array}{c}39.90 \mathrm{~b} \\
\mathrm{~A}\end{array}$ & $\begin{array}{c}30.01 \mathrm{~b} \\
\mathrm{~A}\end{array}$ & $\begin{array}{c}36.77 \mathrm{~b} \\
\mathrm{~A}\end{array}$ & $\begin{array}{c}33.81 \mathrm{~b} \\
\mathrm{~A}\end{array}$ & $\begin{array}{c}37.27 \mathrm{ab} \\
\mathrm{A}\end{array}$ \\
\hline 6 & $\begin{array}{c}54.31 \mathrm{a} \\
\mathrm{A}\end{array}$ & $\begin{array}{c}44.57 \mathrm{a} \\
\mathrm{AB}\end{array}$ & $\begin{array}{c}49.19 \mathrm{a} \\
\mathrm{AB}\end{array}$ & $\begin{array}{c}42.87 \mathrm{a} \\
B\end{array}$ & $\begin{array}{c}47.02 \mathrm{a} \\
\mathrm{AB}\end{array}$ & $\begin{array}{c}48.19 \mathrm{a} \\
\mathrm{AB}\end{array}$ & $\begin{array}{c}43.38 \mathrm{a} \\
\text { B }\end{array}$ \\
\hline
\end{tabular}

Numbers followed by the same uppercase letter in the same row and numbers followed by the same lowercase letter in the same column are not significantly different from the Tukey test at 0.05 .

\subsection{Yield}

The yield of bulbs is more influenced by climatic conditions such as temperature, nutrient, plant spacing and the condition of the seeds used as planting material. There was an interaction between the storage period of seeds and varieties on the wet weight of bulbs per plot and per hectare and dry weight of bulbs per plot and per hectare (Table 7). At storage period of 5 months, wet weight per plot and dry weight per plot were not significantly different than the storage period of 4 months, and began to decrease at 6 months of storage period in all varieties. At the storage period of 5 months, Bima Brebes variety had the highest wet weight of bulbs per plot and Pikatan variety had the highest dry weight of bulbs per plot. The dry weight of the bulbs depends on the weight loss of the bulbs during storage. The yield of bulbs is more influenced by climatic conditions such as temperature, nutrition, plant spacing and the condition of the seeds used as planting material. Dinarti et al. [18] which revealed that high temperatures during the bulb-forming phase will cause an increase in the accumulation of carbohydrates into the bulb and enzymatic activity that increases the process of translocation of sucrose to bulbs.

Wet bulb weight per hectare and bulb dry weight per hectare at the storage period of bulbs of 4 and 5 months were not significantly different, but significantly higher than the storage period of bulbs of 6 months. Yield of web bulbs per hectare of bulb seeds storage period for five months was significantly higher than sitx months for the varietis of Bima Brebes, Katumi, Kuning, Pikatan, Pancasona dan Mentes. At the storage period of 6 months, the wet weight of bulbs per hectare and dry weight of bulbs per hectare decreased by 2-4 periods compared to the storage period of 5 months, depending on the variety. 
Table 7. The interaction effect of seed storage period and varieties on wet and dry weight of bulbs per plot (kg) and per hectare (tons)

\begin{tabular}{|c|c|c|c|c|c|c|c|}
\hline \multirow{2}{*}{$\begin{array}{c}\text { Treat- } \\
\text { ment }\end{array}$} & \multicolumn{7}{|c|}{ Varieties } \\
\hline & Bima & Katumi & Kuning & Pikatan & Trisula & Pancasona & Mentes \\
\hline \multicolumn{8}{|c|}{ Seed storage period (months) } \\
\hline \multicolumn{8}{|c|}{ wet weight of bulbs per plot $(\mathrm{kg})$} \\
\hline 4 & $\begin{array}{c}5.15 b \\
A\end{array}$ & $\begin{array}{c}5.60 \mathrm{a} \\
\mathrm{A}\end{array}$ & $\begin{array}{c}5.39 \mathrm{a} \\
\mathrm{A}\end{array}$ & $\begin{array}{c}4.55 \mathrm{~b} \\
\mathrm{~A}\end{array}$ & $\begin{array}{c}4.50 \mathrm{a} \\
\mathrm{A}\end{array}$ & $\begin{array}{c}4.75 \mathrm{~b} \\
\mathrm{~A}\end{array}$ & $\begin{array}{c}572 \mathrm{a} \\
\mathrm{A}\end{array}$ \\
\hline 5 & $\begin{array}{c}7.03 \mathrm{a} \\
\mathrm{A}\end{array}$ & $\begin{array}{c}5.47 \mathrm{a} \\
\mathrm{AB}\end{array}$ & $\begin{array}{c}6.2 \mathrm{a} \\
\mathrm{A}\end{array}$ & $\begin{array}{c}6.59 \mathrm{a} \\
\mathrm{A}\end{array}$ & $\begin{array}{c}4.28 \mathrm{a} \\
\mathrm{B}\end{array}$ & $\begin{array}{c}6.39 \mathrm{a} \\
\mathrm{A}\end{array}$ & $\begin{array}{c}6.58 \mathrm{a} \\
\mathrm{A}\end{array}$ \\
\hline 6 & $\begin{array}{c}1.97 \mathrm{c} \\
\mathrm{A}\end{array}$ & $\begin{array}{c}1.77 \mathrm{~b} \\
\mathrm{~A}\end{array}$ & $\begin{array}{c}1.83 \mathrm{~b} \\
\mathrm{~A}\end{array}$ & $\begin{array}{c}1.71 \mathrm{c} \\
\mathrm{A}\end{array}$ & $\begin{array}{c}1.73 \mathrm{~b} \\
\mathrm{~A}\end{array}$ & $\begin{array}{c}1.96 \mathrm{c} \\
\mathrm{A}\end{array}$ & $\begin{array}{c}2.25 \mathrm{~b} \\
\mathrm{~A}\end{array}$ \\
\hline \multicolumn{8}{|c|}{ wet weight of bulbs per hectare (ton) } \\
\hline 4 & $\begin{array}{c}13.72 \mathrm{~b} \\
\mathrm{~A}\end{array}$ & $\begin{array}{c}14.94 \mathrm{a} \\
\mathrm{A}\end{array}$ & $\begin{array}{c}14.38 \mathrm{a} \\
\mathrm{A}\end{array}$ & $\begin{array}{c}12.14 \mathrm{~b} \\
\mathrm{~A}\end{array}$ & $\begin{array}{c}12.14 \mathrm{~b} \\
\mathrm{~A}\end{array}$ & $\begin{array}{c}12.66 \mathrm{~b} \\
\mathrm{~A}\end{array}$ & $\begin{array}{c}15.25 \mathrm{a} \\
\mathrm{A}\end{array}$ \\
\hline 5 & $\begin{array}{c}18.75 \mathrm{a} \\
\mathrm{A}\end{array}$ & $\begin{array}{c}14.60 \mathrm{a} \\
\mathrm{AB}\end{array}$ & $\begin{array}{c}16.56 \mathrm{a} \\
\mathrm{A}\end{array}$ & $\begin{array}{c}17.58 \mathrm{a} \\
\mathrm{A}\end{array}$ & $\begin{array}{c}11.41 \mathrm{a} \\
\mathrm{B}\end{array}$ & $\begin{array}{c}17.06 \mathrm{a} \\
\mathrm{A}\end{array}$ & $\begin{array}{c}17.55 \mathrm{a} \\
\mathrm{A}\end{array}$ \\
\hline 6 & $\begin{array}{rc}5.25 & \mathrm{c} \\
\mathrm{A} & \end{array}$ & $\begin{array}{c}4.72 \quad b \\
A\end{array}$ & $\begin{array}{c}4.89 \mathrm{~b} \\
\mathrm{~A}\end{array}$ & $\begin{array}{c}4.56 \mathrm{c} \\
\mathrm{A}\end{array}$ & $\begin{array}{rr}4.56 & \mathrm{c} \\
\mathrm{A} & \end{array}$ & $\begin{array}{c}5.24 \mathrm{c} \\
\mathrm{A}\end{array}$ & $\begin{array}{c}5.99 \mathrm{~b} \\
\mathrm{~A}\end{array}$ \\
\hline \multicolumn{8}{|c|}{ dry weight of bulbs per plot $(\mathrm{kg})$} \\
\hline 4 & $\begin{array}{c}3.88 \mathrm{a} \\
\mathrm{A}\end{array}$ & $\begin{array}{c}3.99 \mathrm{a} \\
\mathrm{A}\end{array}$ & $\begin{array}{c}3.69 \mathrm{a} \\
\mathrm{AB}\end{array}$ & $\begin{array}{c}3.44 \mathrm{~b} \\
\mathrm{AB}\end{array}$ & $\begin{array}{c}2.83 \mathrm{a} \\
\mathrm{B}\end{array}$ & $\begin{array}{c}3.36 \mathrm{~b} \\
\mathrm{AB}\end{array}$ & $\begin{array}{c}3.93 \mathrm{a} \\
\mathrm{A}\end{array}$ \\
\hline 5 & $\begin{array}{c}4.41 \mathrm{a} \\
\mathrm{AB}\end{array}$ & $\begin{array}{c}3.60 \mathrm{a} \\
\mathrm{BC}\end{array}$ & $\begin{array}{c}3.73 \mathrm{a} \\
\mathrm{AB}\end{array}$ & $\begin{array}{c}4.61 \mathrm{a} \\
\mathrm{A}\end{array}$ & $\begin{array}{c}2.69 \mathrm{a} \\
\mathrm{C}\end{array}$ & $\begin{array}{c}4.24 \mathrm{a} \\
\mathrm{AB}\end{array}$ & $\begin{array}{c}4.11 \mathrm{a} \\
\mathrm{AB}\end{array}$ \\
\hline 6 & $\begin{array}{c}0.91 \mathrm{~b} \\
\mathrm{~A}\end{array}$ & $\begin{array}{c}0.99 \mathrm{~b} \\
\mathrm{~A}\end{array}$ & $\begin{array}{c}0.93 \mathrm{~b} \\
\mathrm{~A}\end{array}$ & $\begin{array}{c}0.98 \mathrm{c} \\
\mathrm{A}\end{array}$ & $\begin{array}{c}0.91 \mathrm{~b} \\
\mathrm{~A}\end{array}$ & $\begin{array}{c}1.01 \mathrm{c} \\
\mathrm{A}\end{array}$ & $\begin{array}{c}1.27 \mathrm{~b} \\
\mathrm{~A}\end{array}$ \\
\hline \multicolumn{8}{|c|}{ dry weight of bulbs per hectare (ton) } \\
\hline 4 & $\begin{array}{c}10.35 \mathrm{a} \\
\mathrm{A}\end{array}$ & $\begin{array}{c}10.64 \mathrm{a} \\
\mathrm{A}\end{array}$ & $\begin{array}{c}9.85 \mathrm{a} \\
\mathrm{AB}\end{array}$ & $\begin{array}{c}9.16 \mathrm{~b} \\
\mathrm{AB}\end{array}$ & $\begin{array}{c}7.54 a \\
B\end{array}$ & $\begin{array}{c}8.97 b \\
\text { AB }\end{array}$ & $\begin{array}{c}10.47 \mathrm{a} \\
\mathrm{A}\end{array}$ \\
\hline 5 & $\begin{array}{c}11.75 \mathrm{a} \\
\mathrm{AB}\end{array}$ & $\begin{array}{c}9.60 \mathrm{a} \\
\mathrm{BC}\end{array}$ & $\begin{array}{c}9.94 \mathrm{a} \\
\mathrm{AB}\end{array}$ & $\begin{array}{c}12.30 \mathrm{a} \\
\mathrm{A}\end{array}$ & $\begin{array}{c}7.18 \mathrm{a} \\
\mathrm{C}\end{array}$ & $\begin{array}{c}11.32 \mathrm{a} \\
\mathrm{AB}\end{array}$ & $\begin{array}{c}10.95 a \\
A B\end{array}$ \\
\hline 6 & $\begin{array}{c}2.42 \mathrm{~b} \\
\mathrm{~A}\end{array}$ & $\begin{array}{c}2.63 b \\
A\end{array}$ & $\begin{array}{c}2.48 \mathrm{~b} \\
\mathrm{~A}\end{array}$ & $\begin{array}{c}2.61 \mathrm{c} \\
\mathrm{A}\end{array}$ & $\begin{array}{c}2.43 b \\
A\end{array}$ & $\begin{array}{c}2.70 \mathrm{c} \\
\mathrm{A}\end{array}$ & $\begin{array}{c}3.39 \mathrm{~b} \\
\mathrm{~A}\end{array}$ \\
\hline
\end{tabular}

Numbers followed by the same uppercase letter in the same row and numbers followed by the same lowercase letter in the same column are not significantly different from the Tukey test at 0.05 .

\section{Conclusions}

Shallot bulb seeds of the varieties of Bima Brebes, Katumi, Kuning, Pikatan, Pancasona and Mentes can be stored until five months after harvest, where the quality of bulb seeds can be maintained.

\section{References}

1. Kementerian Pertanian, Data lima tahun terakhir, available at: https://www.pertanian.go.id/home/?show=page\&act=view\&id=61, (Diunduh 27 Mei 2021)

2. Direktorat Perperiodan Hortikultura, Pedoman Teknis Pengembangan Sistem Perperiodan Hortikultura (2011)

3. Y. Giamerti, T. Mulyaqin, Bul. IKATAN. 3, 2 (2013)

4. J.L. Brewster, Crop Production Science in Horticulture 3: Onions and Other Vegetable Alliums $2^{\text {nd }}$ ed. (CAB International, Amsterdam, 2002) 
5. Y. Abdissa, T. Tekalign, L.M. Pant, African J. Agric. Res. 6, 14, 3252-3258 (2011)

6. F.N. Azis, R. Budiono, S. Zunaini S., Agrin. 21, 1, 10-16 (2017)

7. A. Firmansyah, A. Bhermana, Ilmu Pertan. (Agric. Sci). 4, 3, 110 (2019)

8. N. Mashud, Bul. Palma. 32, 52-59 (2007)

9. A.N. Song, Y. Banyo, J. Ilmiah Sains. 15, 1, 166 (2011)

10. Haryadi, J. Anterior. 12, 2, 1-5 (2013)

11. Sutoro, M. Setyowati, Informatika Pertanian. 23, 1, 1-6 (2014)

12. A. Fahn, Anatomi Tumbuhan (PT Gramedia, Jakarta, 1992)

13. M.M.A. El-Magd, M.F. Zaki, F.S.A El-Al, E.H.A. El-Samad, J. Appl. Sci. Res. 9, 2, 1170-1180 (2013)

14. M. Islam, M. Reza, S.M.A.. Kamal, M. Wazed, K. Islam, A Scientific J. Krishi Foundation. 6, 1\&2, 132-139 (2008)

15. R. Kamenetsky, I.L. Shafir, H. Zemah, A. Barzilay, H.D. Rabinowiitch, J. Amer. Soc. Hort. Sci. 129, 143-146 (2004)

16. S.S.M. El-Zohiri, A.A. Farag, Middle East. J. Agric. Res. 3, 4, 1169-1183 (2014)

17. C. Azmi, I.M. Hidayat, G. Wiguna, J. Hortik. 21, 3, 206-213 (2011)

18. D. Dinarti, B.S. Purwoko, Purwito, A.D. Susila, J. Agron. Indones. 39, 97-102 (2011) 